\title{
Relocating Households to Unaccustomed Livelihood: The Impacts of Development-Induced Displacement in Urban Vicinity of Dukem Town, Central Ethiopia
}

\author{
Bikila Ayele Suyum (Corresponding Author) \\ Department of Sociology, Salale University, Fitche, Ethiopia \\ Tell: +251963903878＿Ｅmail: ayelebikila@gmail.com
}

Received: July 22, 2019

Accepted: August 14, 2019

Published: August 14, 2019

doi:10.5296/jas.v7i3.15269

URL: https://doi.org/10.5296/jas.v7i3.15269

\begin{abstract}
Involuntary displacement of people in the context of development projects often causes damage to livelihood of displaced people. The level of livelihood risks and impoverishments is often far reaching when the displaced people are relocated to unaccustomed livelihood settings. This research examined the impacts of development-induced displacement on the livelihoods of households displaced by Addis-Djibouti railway corridor construction in the vicinity of Dukem town. The study used mixed cross sectional research design. In-depth interview, focus group discussion and survey methods were used as tools of data collection. In addition, relevant secondary data were also collected from different secondary sources. The study used Cernea's impoverishment risks and reconstruction model as an analytical framework. The study uncovered that majority of the displaced households have experienced deterioration of economic assets such as landlessness, cattlelessness and joblessness; decline in productivity and food insecurity, socioeconomic marginalization, weakening of social networks and deterioration of access to community services after displacement. Deterioration in access to the livelihood assets due to the displacement has resulted in impoverishments of livelihood of majority of the displaced households.
\end{abstract}

Keywords: development-induced displacement, relocation, livelihood, Dukem, Ethiopia

\section{Introduction}

In many developing countries, displacement of people because of development projects, including infrastructure expansion has been a prominent feature in urban and rural settings (Cernea, 1997; Robinson, 2003; Terminiski, 2013). Cernea (1997) points out that the recently growing investments in development projects and expansion of infrastructures have increased demand for land. To accommodate such development activities, transferring a large amount 
of land for the needed project/investment activity becomes a necessity. However, much of land needed for such a purpose is already occupied by people that lead to displacement and resettlement of the land occupied population. The transfer of land through such a process affects the secured availability and access to household's assets and the overall sustainability of livelihoods.

Displacement due to development projects has profound socioeconomic and cultural disruption for those evicted (Cernea, 1997; Robinson, 2003, World Bank, 2010). World Bank has estimated that every year since 1990, roughly 10 million people worldwide have been displaced involuntarily by infrastructural development projects and investments. Although population displacement has been a prerequisite of growing economies, especially in developing countries, it affects the livelihoods of the households who are involuntarily displaced to allow such development projects to take off (Cernea, 1997). The development projects can bring enormous benefits to society; they also impose costs, which are often experienced by its poorest and most marginalized rural and urban households.

Some of the recent empirical studies indicate that many of the development investments and projects carried out in recent years have not only failed to increase the well-being of resettled people, but have actually increased their multigenerational marginalization (Robinson, 2003; World Bank, 2010). Study conducted by World Bank (2010) indicated that involuntary resettlement under development projects, if unmitigated, often leads to severe socioeconomic and environmental risks; give rise to failure of production systems; people are relocated to environments where their productive skills may be less applicable and the competition for resources greater; community institutions and social networks are weakened; kin groups are dispersed; and cultural identity, traditional authority, and the potential for mutual help are diminished or lost. Unfortunately, many people who are displaced by development activities are not properly resettled and rehabilitated (Robinson, 2003; Terminski, 2013; Cernea, 1997).

In the Ethiopian context, displacement is common in development projects and investments aimed at economic growth and social transformation. Recent studies have indicated that development-induced displacement in Ethiopia has become the most significant type of movement replacing earlier concerns with resettlement, refugees, returnees and demobilization (Pankhurst and Piguet in Eguavoen and Tesfai, 2012). Recent studies (Yintso, 2008; Tadele, 2009; Zinawi; 2012; Kassahun, 2011; Berhanu, 2006; Nebiyu, 2000; Obsa, 2013) indicated that development projects such as dam constructions, urban renewal, agricultural investments, and infrastructures expansions have been caused displacement of thousands of people in rural and urban areas of Ethiopia.

However, there are limited empirical evidences on the increasing crises of development-induced displacements of urban fringe households. This research focuses on the socioeconomic impacts of relocating farm and/or mixed farm households to unaccustomed urban setting that is neglected in the previous studies. To fill this gap, the study is primarily intended to investigate the impacts of development-induced displacement and relocation on the livelihoods of displaced people in the case of households displaced by Addis-Djibouti railway corridor construction in the vicinity of Dukem town, Oromia, Ethiopia. Cernea's 


\section{Mll Macrothink}

impoverishment risks and reconstruction model was used as theoretical and conceptual framework of the study.

\section{Materials and Methods}

Description of the Study Area: The study was conducted in Tedecha kebele, Dukem town area, Oromia, Ethiopia in 2014. Dukem is located at 37 kilometers South East of Addis Ababa. The astronomical location of Dukem is between $8045^{\prime} 25^{\prime} \mathrm{N}-8050$ ' 30 " $\mathrm{N}$ latitude and 38051'55"E - 38056'5" E longitude. Dukem town has one urban kebele and three rural kebeles (the smallest administrative unit) surrounding the town: Tadacha, Dukem Koticha and Mendelo.

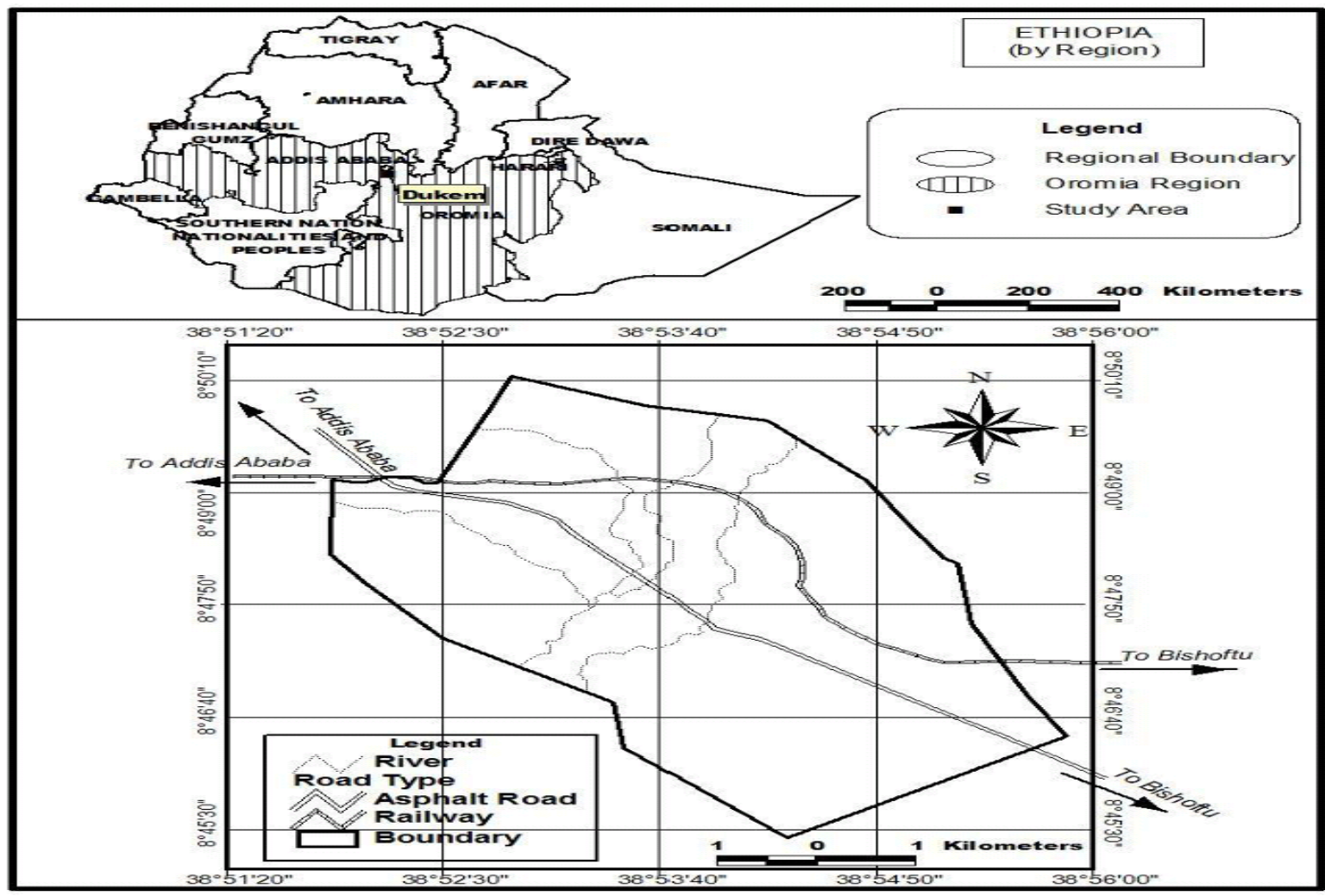

Figure 1. Location of the study area

Methods of data collection: In this research, both qualitative and quantitative methods of data collection were used. The research was intended to undertake an intensive investigation on displaced household's livelihood condition after displacement. Thus, the research is mainly qualitative and descrptive quantitative data was also collected to supplement the qualitative data of the study. To this end, in-depth interview, focus group discussion (FGD) and survey methods of data collections were employed.

In-depth Interview: To explore the livelihood situation of displaced households and their experience of the impacts of the displacement, key informants and displaced households were interviewed by using the in-depth interview guide. For this porpuse, 12 displaced household heads, 3 elders, 3 officials and 2 extension workers were interviewed. 
FGD: FGD was also used to collect information on the livelihood situation of the displaced households. For this purpose, two FGDs with ten discussants in each group were held with selected displaced household heads. The responses collected through FGDs were used to collect in-depth information on the livelihood situation of the households after displacement. It is also used to cross check information obtained through other data collection tools.

Household Survey: Survey data collection instrument consisting of both close-ended and open-ended questions was utilized to collect quantitative data on the socioeconomic and demographic data of the respondents, household assets conditions before and after displacement. Out of 230 total displaced households from Tedecha kebele, the data was collected from the sample of 70 displaced households.

Documentary Review: Relevant documents were also reviewed to understand the trends of displacement as a current social issue in the context of worldwide in general and in the Ethiopian context in particular. Any document and literature that add value to answering the research objective were assessed and analyzed.

The population of the Study: In this study, the target population was all the 230 households displaced by Addis-Djibouti railway corridor construction in Tedecha Kebele of Dukem town in Oromia special Zone surrounding Finfinne, Oromia region, Ethiopia.

Sampling Design and Sampling Technique: Both probability and non-probability sampling methods were used. Therefore, the units of data collection for the key informant interview and FGDs were selected purposefully. The study also used systematic sampling as the sampling frame (list of the respondents) was available. The sample size of the respondents of the survey was determined based on the published table (Yemane in Glenn, 1992) which provides the sample size for a given set of criteria. The published table presents sample sizes that would be necessary for a given combination of precision, confidence level, and variability. Based on this approach, out of 230 total household population of the study, 70 households were selected for the sample survey.

Methods of Data Analysis: A combination of qualitative and quantitative methods of data analyses were used to analyze data from various sources. The analysis of qualitative data was started during actual data collection; because the process of qualitative data collection and analysis are interwoven. The data gathered through an interview, FGDs and observation methods were analyzed qualitatively. The quantitative data collected through a sample survey were coded, categorized, organized and analyzed using descriptive statistics. In the data analysis section, quantitative data were put together with qualitative data to get a comprehensive conclusion of the findings.

\section{Effects of Development Induced Displacement}

The ultimate goal of human development, including economic development, should be the improvement of individual and collective life (Robinson, 2003; Cernea, 2008; Terminski, 2013). Implementation of large development projects is then expected to serve the broad economic interests of the country and so maximizes the well-being of its citizens. Cernea, (2008) takes the stand that the primary goals of the development projects involving 
population displacement are to contribute to poverty reduction but many development projects have been blamed to cause impoverishment by forcibly displacing people and lead them to poverty life.

According to Terminski (2013) economic growth must be accompanied by an increase in the level of education, along with better access to health care institutions, social services and other activities aimed at maximizing human capitals. However, the principles expressed above are still very far from actual implementation in many parts of the world. He argues those only dominant groups exclusively are beneficiaries of economic growth. This way economic development is not designed in a way to improve the lives of all the inhabitants of a country, but to serve the interests of government, private business or narrow social elites.

Development-caused displacement has had especially negative social consequences in countries characterized by a land-based economy and low employment flexibility, together with strongly rooted social stratification. (Downing, 2002) indicated that there are varieties of effects which displaced household's experience, but the major effects include reduction of income, loss of assets and means of livelihoods. Other effects of displacement include stress to the vulnerable people, including women, children and elderly, disruption of social networks, loss of economic status, psychological and social stress and effects on human rights. According to Robinson (2003) displacement is associated with increased vulnerability, including impoverishment, increased morbidity and mortality, loss of social and economic rights and in many cases abuse of human rights. Koenig (2009) also revealed that the relocation of communities by development project often leads to violation of human rights. Cernea (2000) uncovered that indigenous groups and ethnic minorities make up a disproportionately large percentage of those who absorb the adverse effects on livelihoods due to development projects.

Displacement causes extreme effects to indigenous people, because as Downing (2002) indicated, indigenous people largely depend on their surrounding environment and change in the surrounding environment affects individual and community adaptive responses and result in displacement and also can adversely affect their culture. Carino (1999) also added that development project induced displacement leads to loss of livelihood resources, weakening of traditional values, loss homeland and burial place and loss of properties inherited over many generations. The loss of livelihood assets such as land and home associated with displacement frequently has adverse impacts on people, especially women, children and disabled peoples who are vulnerable to violence, poverty, impoverishment and marginalization. Koening (2002) indicated that women consume the adverse impacts of displacement than men due to loss of access to individual gardens, reduced ability to produce food and reduced women power within the family due to greater dependence on their husbands. Moreover, development induced displacement causes breakdown in the function of schools and interrupt children access to education, especially during the period of transfer, but sometimes last for a longer period of time (Downing, 2002).

\section{Theories of the Impacts of Development Induced Displacement}

Various models have been used to highlight the effects of development project induced 
displacement. In this study Scudder and Colsons' 'the four stages stress centered model' developed in (1982) and Michael Cernea's 'the Impoverishment Risks and Reconstruction model (IRRM)' developed in 1997 are discussed below.

\section{The Sudder-Colson Stress Centered Model}

The four stage Sudder-Colson stress centered model includes the recruitment stage, the transition stage, the potential development stage and the handing over or incorporation stage. The model is known for its four stages of resettlement process that is believed to be the same across resettlement projects and expected to be achieved over two generations (Scudder, 1997). Planning the first stage is a process of infrastructure development and settler recruitment. Transition is a period during which the social and cultural system is closed and when stress is at its climax. At this stage there exists neither innovation nor revitalization within the community since people behave in a risk adverse style generations (Scudder, 1997). The potential development stage is early stage, which lasts for more than one year gives a way to potentially development and community formation. It is a time when the people with adequate support begins to construct their economy and revitalizes their social and cultural life. The last stage is when the relocatees hand over successful to their children. Hence the second generation see themselves as equal members of the host communities (Scudder, 1997). Each of these stages work across any resettlement conditions, policy and any other differences related to process of relocation (Scudder and Culson, 1982).

\section{Impoverishment Risks and Reconstruction Model (IRRM)}

Another theoretical model named Impoverishment Risk and Reconstruction Model (IRR) developed by Michael Cernea (1997) is a conceptual/theoretical model which analyses key risks that are caused by involuntary displacement and resettlement that leads to impoverishment. Although his model has been initially developed to document the effects of involuntary displacement caused by major development projects, recently a number of researchers have found it applies in other dislocation contexts, including displacement caused by war and refugee situations, and other involuntary relocations. The theoretical model also provides measures to mitigate the impoverishment risks caused by involuntary displacement and the reconstruction of livelihoods.

\section{Impoverishment Risks}

Cernea's model proposes that the beginning of impoverishment can be represented through a model of eight interlinked potential risks to displacement; but recently added two elements which include:

Landlessness: Expropriation of land removes the main foundation upon which people's productive systems, commercial activities, and livelihoods are constructed. This is the principal form of de-capitalization and pauperization of displaced people, as they lose both natural and human-made capital.

Joblessness: The risk of losing wage employment is very high both in urban and rural displacements for those employed in enterprises, services, or agriculture. Yet, creating new 
jobs is difficult and requires substantial investment. Unemployment or underemployment among resettlees often endures long after the physical relocation has been completed. Job loss due to displacement causes lasting economic and psychological effects on affected people.

Homelessness: Involuntary displacement and relocation often leads to the loss of shelter/housing. In a broader cultural sense, loss of a family's individual home and the loss of a group's cultural space tend to result in alienation and status deprivation. For many households, the loss of shelter can be temporary, but some of the households remain permanently homeless or they end up in substandard housing. The loss of home and disruption of family members may lead to social exclusion and diminish the social status of the individuals/households.

Marginalization: Marginalization occurs as a result of families' loss of economic power and spiral on a downward mobility path. Many individuals unable to use their earlier skills at the new location; lost their human capital or remain inactive. Economic marginalization often leads to social and psychological marginalization, reduced social status, loss of confidence in society and in themselves, a feeling of discriminated and dependent on others.

Food Insecurity: Forced displacement increases the risk of food insecurity and undernourishment due to decrease in food production or income earnings during the relocation period. Reestablishing food production may take a longer period of time leading to temporary or chronic undernourishment.

Increased Morbidity and Mortality: Massive population displacement often causes diminished health status. Displacement and relocation induced social stress and psychological trauma, and other chronic epidemics are sometimes accompanied by the outbreak of relocation related illnesses, particularly parasitic and vector-borne diseases such as malaria and schistosomiasis which often affect vulnerable groups including elderly, children and the infants.

Loss of Access to Common Property: Lack of access to common property assets, including burial grounds, open spaces, access to public services has adverse effects on livelihoods.

Social Disintegration: Forced population displacement is the causes of profound disruption of existing patterns of social organization. The dismantling of communities leads to the destruction of social organization and social ties, including neighborhood networks, life sustaining informal networks of mutual help, local voluntary association and self-organized mutual services which form the basis of social capital. When people are displaced, production systems are disrupted.

Downing (2002), introduced risks such as the loss of access to public services, loss of access to schooling for school-age children, and the loss of civil rights or abuse of human rights. Uprooted communities often face limited access to health centers, schools and educational facilities and children's loss of educational opportunities. Removal from one's original home and the loss of property without proper compensation itself, constitute a violation of human rights. Moreover displacees often face violation of civil, political, economic and social rights. 


\section{The Risk Reversal}

The risk reversal is a framework for social, economic reestablishment and rehabilitation of the displaced people. Cernea (1997) point out that the impoverishment risks that has been discussed above can be resolved or minimized through the risk reversal elements. It predicts the adverse outcome of the involuntary displacement and resettlement and provides guidance to deal with the impoverishment risks and resolving the problems caused by displacement and thus providing a way forward for livelihood reconstruction for the displaced households. Cernea (2000) further asserts that the model can be used to predict the possible risks and provide proactive measures or at least minimize prior to the actual happening of the risks emphasizing two important approaches; 1) the need for solid strategies to prevent impoverishment and 2) the need for financial assistance to support the strategies of risk reversal.

Cernea (1997) argues mitigating and minimizing the risks of impoverishment needs an integrated approach, indicating dependence on a single strategy, for instance cash compensation alone do not respond to and resolve all risks of impoverishment. He argued greater involvement of the displaced population and other stakeholders in the resettlement and relocation process, local leaders, nongovernmental organizations and host population bring great significance in rebuilding the livelihood of affected populations. The involuntary resettlement process needs to adopt strategies that can prevent impoverishment and enable displacees to reconstruct and improve their livelihoods. The following are components for reversing the risks of impoverishment;

\section{From Landlessness and Joblessness to Land Based Rehabilitation and Reemployment}

Settling displaced people back on farmland or in income-generating employment is the determinant of livelihood reconstruction. This could be achieved by identifying equivalent lands; bringing new lands into production through land recovery; crop intensification or a shift to more valuable crops; diversification of on-farm/off-farm activities; and use of project-created productive resources such as reservoirs, irrigated areas downstream, etc. To ensure sustainability of household's income investments for creating sustainable new employment in the relocation area are very essential. This helps displaced people to get back into income generating employment.

\section{From Homelessness to House Construction}

Cernea (1997) uncovered that impoverishment of homelessness can be effectively prevented by providing fair housing construction compensation. Providing better shelter is an easier component to achieve in reconstructing livelihood. By establishing and supporting resettlers initiatives it is possible to create improved housing condition for affected people. These could be done through organizing mutual support, mobilization of family labor, shifting parts of the compensation for land towards home building and incremental construction.

\section{Overcoming Marginalization, Social Disarticulation and Loss of Community Assets}

Cernea (2000) points out the importance of effective reconstruction of communities, social 
networks, and social cohesion in reconstructing displaced and relocated communities. Community reconstruction refers to group structures, including informal and formal institutions, while overcoming marginalization refers primarily to the individual family/household level. Different approaches can be used in creating neighborhoods as new social units that need new community assets and public services or in reconciling the host community with resettlers.

\section{From Food Insecurity to Adequate Nutrition and from Morbidity to Better Health Care}

Nutrition levels and health status level of displacees will depend in the long run on progress in relocatees livelihood rehabilitations specially economic recovery. To ensure adequate nutrition and better health care need for immediate response in terms of organized assistance is recommended. Immediate nutritional and health risks to affected people must focus on the most vulnerable groups such as children, the elderly, pregnant women.

\section{Findings and Discussions}

5.1 Age, Educational Status and Household Size of the Respondents

Table 1. Age, Educational Status and Household Size of the Respondents

\begin{tabular}{llcc}
\hline Variables & Categories & \multicolumn{2}{c}{ n=70 } \\
\cline { 3 - 4 } & & Frequency & Percentage \\
\hline \multirow{3}{*}{ Age } & $20-30$ & 10 & 13.7 \\
& $31-45$ & 38 & 52.1 \\
& $46-59$ & 17 & 24.3 \\
\multirow{3}{*}{ Educational status } & $20-30$ & 5 & 6.5 \\
& Illiterate & 17 & 23.3 \\
& Primary (1-8) & 36 & 49.4 \\
& Secondary (9-12) & 11 & 15.1 \\
& Degree and above & 6 & 8.2 \\
\hline \multirow{3}{*}{ Household size } & $1-3$ & 15 & 20.5 \\
& $4-7$ & 41 & 56.3 \\
& 8 and above & 14 & 19.2 \\
\hline
\end{tabular}

\section{Source: Field Survey, 2014}

Table 1 indicates that majority of the respondents were categorized in the age group of 31-45 $(52.1 \%)$ followed by $46-59(23.3 \%)$. The majority of the respondents, $36(49.4 \%)$ have attended elementary school followed by illiterate 17 (23.3\%). Secondary level and college diploma/degree constitutes $11(15.1 \%)$ and $6(8.2 \%)$ respectively. The above table also shows that majority of the sample households $41(58.6 \%)$ have a household size of 4 to 6 members. While $15(20.5 \%)$ and 14 (20\%) of the respondents have less than 4 and 8 and above household members respectively. 
Table 2. Respondents main source of income before and after displacement

\begin{tabular}{llcc}
\hline Variables & Categories & \multicolumn{2}{c}{ n=70 } \\
\cline { 3 - 4 } & & Frequency & Percentage \\
\hline Main source of income & Farming & 26 & 52.9 \\
before displacement & Non-farm(daily labor, petty trade) & 2 & 36.5 \\
& Permanent employment & 5 & 2.9 \\
& Unemployed & 11 & 7.1 \\
\hline Main source of income & Farming & 34 & 15.1 \\
arter displacement & Non-farm(daily labor, petty trade) & 2 & 48.6 \\
& Permanent employment & 23 & 2.9 \\
& Unemployed & & 32.4 \\
\hline
\end{tabular}

\section{Source: Field Survey, 2014}

Regarding respondents main source of income before displacement, farming activities were the major source of income of the sampled households accounting for 37 (52.9\%) followed by non-farm activities $26(36.5 \%)$. Permanently employed respondents constitute only 2 $(2.9 \%)$ while the remained respondents $5(7.1 \%)$ were unemployed before displacement. The number of households who depends on non-farm activities as main source of income has increased to $34(48.6 \%)$ after the displacement. The number of households who have no source income is also increased to $23(32.4 \%)$ after the displacement, while the number of households depends on farming decreased to $11(15.1 \%)$ and the number of permanent employees remain the same $2(2.9 \%)$.

\subsection{The Impacts of Displacement on the Livelihoods of the Displaced People}

\subsubsection{Households Loss of Economic Assets: Landlessness, Cattlelessness and Joblessness}

Development induced displacement primarily affects displaced peoples basic assets such as land, livestock and job. Landlessness, cattlelessness and joblessness are interrelated risks caused by displacement, especially in the case of land based farm households. The following table presents the farm land ownership before and after displacement.

Table 3. Farmland ownership before and after displacement

\begin{tabular}{lcc} 
Characteristics & \multicolumn{2}{c}{$\mathbf{n = 7 0}$} \\
\cline { 2 - 3 } & Frequency & Percentage \\
\hline Households who have farm land before displacement & 37 & 52.9 \\
Households who lost their farm land after displacement & 28 & 39.4 \\
\hline
\end{tabular}

Source: Field Survey, 2014 


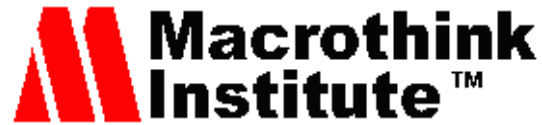

Table 3, shows that $37(52.9 \%)$ of the total sampled population have a farmland before the displacement. However, out of 37 land based farm households, the majority, 28 (39.4\%) of the sampled respondents have lost their farm land after the displacement. The expropriation of farmland resulted in the loss of land related capitals such as crop production, livestock rearing, garden fruits and vegetables, production of honey and marketable trees like eucalyptus and tid. The majority of the respondents' livelihood had been directly or indirectly dependent on agricultural activities and the livelihoods of households who rely on land related economic activities were seriously affected.

The interviews and FGDs responses indicate that landlessness and cattlelessness are the major adverse impacts of the displacement and it exposed the majority of the farm households to livelihood risks. Landlessness in this context does not only refers to the loss of farmland, but also loss of the garden, a place of small businesses and loss of any other piece of land on which socioeconomic livelihood activities of the households had been based. Thus, the victims of landlessness were not only farm households but also other types of households who had lost land on which their basic livelihood activities have been based. However, many of the farm households have been totally dependent on traditional farming where livelihood is dependent on the availability of farmland and agricultural production. Thus, landlessness more affected farm households exposing them to lose of agricultural production and land based assets.

Key informants also revealed that farm household socioeconomic well-being is measured by the size of their farmland and cattle owned. However, larger size ownership of livestock needs access to grazing land. Thus, vulnerability to landlessness also affected displaced households' ownership of livestock. The households shift to rent house or relocation village affected household's capacity to keep their cattle and other livestock due to lack of grazing land and place to keep them. Non-farm households who engage in small garden agriculture were also lost their garden during the displacement. A number of households have lost their informal business activities such as a place to sell food, local drinks and gullit. This increased the number of households who have lost their source of income during the displacement. The majority of the displaced households who lost their farm land, business activities and other means of livelihood became jobless.

Table 4. Respondents who have lost their main source of income due to displacement

Characteristics

$\mathbf{n}=\mathbf{7 0}$

Percentage

Did you lose your main source of income

Yes

45

64.3

after the displacement?

No

25

35.7 
Table 4 indicates that majority of the displaced households, 45 (64.3\%) faced loss of job due to the displacement. Loss of the main source of income/job in this context is associated with loss of farming activities, stopping of garden agriculture, loss of nonfarm activities such as informal local drink, food and petty trade. However, 25 (35.7\%) of the respondents do not lose their main source of income after displacement. Such households were permanently employed or engaged in non-farm economic activities amd thier livelihood does not depend on availability of farm land.

The success of a livelihood restoration often depends primarily on the resolution of basic livelihood asset issues such as land and employment (Cernea, 1997, 2000, Robinson, 2003; Terminiski, 2013). The loss of land, for instance, is a key feature of many resettlement programs (Cernea, 2000). However, recently resettlement plans recommends a greater understanding of the dynamics of large development projects in rural areas, where households predominantly derive their income from their land. The expropriation of land removes the main foundation of households on which they build their production systems, commercial activities, livelihoods and residence. Land taken away from people in the name of development is often lost forever; sometimes partially replaced, seldom fully replaced or fully compensated. This often resulted in de-capitalization and pauperization of the people who are displaced as both natural and man-made capital are lost. Moreover, landless household livelihood that mainly depends on land often exposed to joblessness.

However, the Impoverishment Risk and Reconstruction model neglected the place of live stocks in the livelihoods of displaced farm households as the impoverishment risk emphasized the loss of agricultural productivity and neglected the significance of movable socioeconomic assets-the cattle (Kasahun, 2001). He argued that cattlelessness rarely considered as an element of displacement risks, even at risk of loss of access to common property resources which is believed to include common grazing land and hence cattle.

\subsubsection{The Challenges of Life in Rent House and Feeling of Homelessness}

This research revealed that the majority of the respondents $(78.6 \%)$ were forced to stay in rent house right after the displacement; (5.7\%) settled in their own extra house, and $(5.7 \%)$ were settled in their relative's house.

Table 5. Place of residence before and after displacement

\begin{tabular}{lccc}
\hline Place of residence & Time & n=70 & \\
\cline { 3 - 4 } & & Frequency & Percentage \\
\hline & Right after displacement & 55 & 78.6 \\
Live in rent house & & 4 & 5.7 \\
Live with relatives & & 11 & 15.7 \\
& & 44 & 62.9 \\
Live in rent house & One year after displacement & 2 & 2.8 \\
Live with relatives & & 24 & 34.3 \\
Live in own house & & & \\
\hline
\end{tabular}

Source: Field Survey, 2014 
A year after the displacement, $62.9 \%$ of the households were living in a rent house while $34.3 \%$ were living in their own house. The research also revealed that house/shelter is one of the most problematic household assets. Loss of own house forced the majority of the displaced households to shift to rent house right after the displacement. This created a difficulty to the displaced households as it is very difficult for extended and large farm families and/or households with huge movable properties and livestock to live in a small rent house.

The study also revealed that only a few of the displaced households were able to construct houses in the relocation center and shifted to their own house after a year. The compensation payment given to the displaced households was spent on various domestic consumptions and many households could not complete construction of the replacement houses. Moreover, the households in the rent house were in critical condition due to the unavailability and/or un-affordability of large size rent, houses for extended family members and their movable properties including livestock. In line with this, one of the key informants said;

"I have two milk cows, poultry and three ships before the dislocation and we have been keeping them in our compound. I have large compound and there was house for these live stocks before the displacement. After I came to the rent house, the owner told me that it is impossible even to bring my dog there let alone other big live stocks. I was forced to sell the sheep and one of my milk cows and the one is still with my relative in another compound."

Informants also noted that there is difference in capacity and effective use of the compensation money to be invested on house construction. Those households, who were well-off, permanently employed were able to construct their own house in the relocation village. However, the majority of the farm households were unable to construct the replacement house and still live in a rent house. The statement of one respondent witnessed the condition as follows;

"I have been living in a rented house for more than one year. Now the money that gave us for house construction is finished, but still I couldn't construct my own house on the given land. We have been using the compensation money for home consumption since we stop producing crops by ourselves. We are facing unbearable challenges in a rent house and we are not feeling home now. Our future is dark unless the government takes a measure considering our current problem."

Data from key informants and FGDs also revealed that the delay of house construction exposed households in rent house to shortage of money. This creates the fear of homelessness as the money of compensation is finished on home subsistence and consumption; and the cost of house construction is increasing over time. The majority of the informants who were living in a rent house reported that they feel homelessness as their life in rent house worsened their socioeconomic conditions. According to Cernea (2000) many people may face temporary loss of housing and shelter, but for some it remains for long periods. Loss of residence is not only loss of housing and shelter, but it also often results in disruption of family cohesion and mutual help patterns of neighboring ties as a group get scattered. According to Vanclay (2017) moving, relocation of people to temporary dwelling is one indicator of poor practice of 
resettlement. In case temporary relocation is mandatory, adequate compensation and other benefits should be appropriately delivered to the affected people (Reddy et al. in Vanclay, 2017).

\subsubsection{Declining of Agricultural Productivity and Households in Onset of Food Insecurity}

The food security of households depends on availability of the means of production and stable source of income. According to key informants, the displaced households were reducing their nutrition to save money and reduce the risk of food insecurity. The informants revealed that the probability of households 'exposure to food insecurity is very high because many landless and jobless households have no stable source of income. The farm households who often supply food crops for markets were then purchasing for home consumption.

Before the displacement, local people have arrangements to assist each other in times of food crisis. Especially, relatives, members of the kin group and other social networks support each other giving food crop for starving family. However, the displacement made the displaced people dependent on a market for food consumption and the mutual assistance is weakened after the displacement. One of the displaced households revealed the condition saying;

"Before, I'm known by supplying quality teff for market, but today my wife is purchasing tiff and other crops for food consumption. My children are not getting their nutrition as before because our food access now depends on the market. We have decreased the quality and quantity food after the last four months because we fear the occurrence of hunger as our capacity to obtain food for our family is declining. "

Key informants also indicated that the problem of food security is aggravated by the loss of a source of income, size of household's productive members and effective use compensation money. Food grain purchased from market for large rural household members needs high expense while the majority of the households were actually unable to satisfy their household's balanced diet.

Forced displacement often reduces self-sufficiency of households, dismantles local arrangements for food supply, and thus, increases the risk that people will fall into chronic food insecurity. Increased food insecurity is both a symptom and a result of inadequate resettlement (Cernea, 2000). When affected community depends on rural production systems and is resettled in rural areas, it often takes longer period of time for them to re-store their agricultural activities and ensure household food security.

\subsubsection{Socioeconomic Marginalization of Households}

The study revealed that the gradual deterioration of household's livelihood assets was mainly observed among the vulnerable households. As discussed above, the loss of basic economic assets such as land, cattle and sustainable source of income deteriorated the overall livelihood situation of the displaced households.

Table 6 reveals that $71.4 \%$ of the respondents were claimed that their overall economic situation is deteriorated after the displacement, $12.9 \%$ were responded that their current socioeconomic situation is highly worsened. The table also indicated that the overall 
socioeconomic situation of $11.4 \%$ of the respondents was not changed after the displacement while only $4.3 \%$ of the respondents viewed that their overall socioeconomic condition is improved after the displacement.

Table 6. The overall socioeconomic condition of displaced households after displacement

\begin{tabular}{lcc}
\hline Socioeconomic condition after displacement & \multicolumn{2}{c}{$\mathbf{n = 7 0}$} \\
\cline { 2 - 3 } & Frequency & Percentage \\
\hline Improved & 3 & 4.3 \\
Remain unchanged & 8 & 11.4 \\
Deteriorated & 50 & 71.4 \\
Highly deteriorated & 9 & 12.9 \\
\hline
\end{tabular}

\section{Source: Field Survey, 2014}

According to key informant interviews and FGDs, the majority of the displaced households faced socioeconomic marginalization. The respondents stressed that the main causes of household's economic marginalization were landlessness and joblessness (discussed in the previous sections). Households who have no experience of non-agricultural activities felt their skill and experience got obsolete. One of the respondents expressed his feeling of socio-economic marginalization as follows;

"Before we were displaced from our farm land, I was one of the well-off farmers in the area. I had much cattle; milk cow, farm oxen and fattened oxen for sale; and I produce many quintals of teff and wheat. I was known and respected man in the village. After the displacement, however, I sold my live stocks except the milk cow and oxen, I lost my farmland, and now I feed my family by purchasing tiff from the market. Now, we are in poverty because households, who used to be enough for others before displacement, now became destitute and dependent on others. For farm households, there is no sign of poverty than buying crop from market for food consumption. If the situation goes this way, it is inevitable that we ask government for food assistance."

FGD results revealed that farm households' livelihood is attached to agricultural model of economic activities which is exposed to the challenges of adopting non-agricultural forms of economic activities. This condition not only creates deterioration in the economic status of households, but it also led to the loss of social fame in their community. Farm households who have permanently lost their farmland became jobless and forced to engage in unproductive and un-experienced non-farm activities. The deterioration of basic sources of financial capitals of the majority of households resulted in income insecurity and livelihood crises which are resulted in socio-economic marginalization of the households.

According to Cernea (2000), marginalization is a process through which relocated households lose their economic power and slide down towards marginal socio-economic positions. Such a way, middle income farm-households become landless or small landholders; individuals/ households with small private business stop their activities and become jobless poor; job skills and experience become useless and obsolete in the new socio economic activities. This leads to drop in social and economic status of households (Cernea, 1997; Downing, 2002). 


\subsubsection{Social Disarticulation and Weakening of Social Networks}

The social capitals of the displaced households were local level informal institutions such as $i k k u b$, iddir, mahber and debo that provide mechanisms for mutual help in time of need; solve immediate socio-economic crisis among members, resolve conflicts and increase socioeconomic power of their members. The social networks of family, relatives, neighbors and other local level social ties are also a crucial element of social capital in the area. According to key informant interviews, the weakening of social capitals of the community was due to dispersion of families, relatives, neighbors and members of the social networks to different locations to search for residential house during the relocation. One of the informants said;

"In our previous residence, we have so many mutual assistance mechanisms; we have neighborhood ties that will be there for you in times of a problem, whom you share your happiness and your sorrow; who lend you a money when you need a money, who give you a crop and even food when you hungry; who give you a water when you thirsty. We have a strong odor and equip before the displacement, but now we rarely see each other and not strong as before. The old iddir and ikkub are now weakening due to dispersion of its members. Before, we construct houses in one or two days because we work in debo or mahber with little expense; but now I have been constructing this small house for almost four months. This is created due to lose our old social ties."

According to FGDs results, the displaced household's old social networks such as neighborhood, relative ties and debo arrangements were deteriorated due to disruption of old social setting, lack of regular contact and dispersion of members to different directions in search of a residential house. The iddir, ikkub and mahber of many displaced households were not effectively functional as before. The farm household often depends on labor sharing social network arrangements which depend on neighborhood, family and relative ties. However, these ties were more weakened than any other types of social networks. Although the displaced households were relocated in nearby quarter of their old residence, their shift to rent house in different direction weakened their old social ties. The weakening of social capitals in turn weakened traditional mutual support mechanisms after the displacement.

Forced displacement often dismantles the existing social fabric (Cernea, 1997; Robinson, 2003; Terminiski, 2013). It disperses and fragments communities, dismantles patterns of social organization and interpersonal ties; scatters kinship groups and neighbors. Informal networks of reciprocal help, local voluntary associations, and self-organized mutual service is disrupted. Such social disarticulation undermines livelihoods in ways usually not recognized and not measured by planners, and is a cause of disempowerment and impoverishment. The social impacts of resettlement are difficult to measure, and are often underestimated and undercompensated. The availability and participation in social capital creates a strong and mutually reinforcing relationship between family members, relatives and kin groups, neighbors and determines community cohesion and the displaced household's capacity to cope-up with the impoverishments and risks associated with displacement. 


\subsubsection{Loss of Access to Community Services}

Displacement may cause impoverishment risks such as 'the loss of access to public services' (Mathur 1998, 1999) or 'temporary loss of access to schooling for school-age children caught in the throes of displacement' (Mahapatra1999a). This section deals with the current situation of displaced households' access to basic services and needs such pure water, market, schools and health centers as compared to their ability to access the same services before the relocation. The availability and access to road services to the urban vicinity households is very crucial because household's access to other services such as health services, market services, school and other urban services is affected by the availability and access to road. It helps to take sick person to health centers, to move crops, live stocks and other products to marketplace and enhance socio-economic interactions and promote other assets. Table 7 shows that access to the basic social services such as market place, pure water, school and health center is deteriorated for the majority of the displaced people after the displacement.

Table 7. Respondent's access to basic social services

\begin{tabular}{l|cc}
\hline \multirow{2}{*}{ Services } & \multicolumn{2}{c}{$\mathbf{n = 7 0}$} \\
\cline { 2 - 3 } & Access remain unchanged & Access deteriorated \\
\hline Market place & $16(22.9 \%)$ & $54(77.1 \%)$ \\
Pure water & $25(35.7 \%)$ & $45(64.3 \%)$ \\
School & $6(8.6 \%)$ & $64(91.4 \%)$ \\
Health center & $5(7.1 \%)$ & $65(92.9 \%)$ \\
\hline
\end{tabular}

\section{Source: Field Survey, 2014}

According to key informants, the construction destroys the old roads, cut off relatives and neighbors away from seeing each other. The majority of the displaced households were settled in temporary rent houses far from the village main road to get cheap and large compound houses. This, in turn, exposes the households to road, electricity and water problems. Access to the basic social services is deteriorated not only due to the distance of the social services from displaced household's residence, but also due to the lack of capacity, and low government attention to the problem. The new resettlement village has no road, pure water and electricity. Though the resettlement village is very near to the town, the relocated household's access to the basic services is very poor and this condition has mainly increased burden on women. Those who have shifted to their new house in the relocation village were facing the challenges of fetching water from long distance either by cart, donkey back or human power. Lack of electricity also increased the need for firewood collection, which is not easily available in the area. This problem is mainly affecting women and children of the displaced households.

\section{Conclusions and Recommendations}

\subsection{Conclusions}

The study has found that households displaced from Dukem area have faced the impoverishment risks-loss of the basic economic assets (landlessness, cattlelessness and 
joblessness), feeling of homelessness, decline in agricultural productivity and food insecurity, socio-economic marginalization, social disintegration and loss of access to community services.

The farmland of the majority of the displaced households was taken away for the construction of railway corridor and resulted in landlessness, cattleless and joblessness. Loss of a farmland has affected the economic assets of the displaced households. The other big challenge faced by displaced households is the difficulty of living in rent house, especially for households with large family members and livestock. The majority of the displaced households couldn't construct a house, even after a year of the displacement. The delay of residential house construction has exposed households in rent house to shortage of money and gradual loss of capacity to build their own house. This is mainly due to the fact that the money that was given for compensation was finished on home subsistence and consumption; and the cost of house construction was increased over a period of time. The challenges that the displaced households were facing in the rent house have also created the feeling of homelessness among the majority of the displaced households. The displacement and relocation adversely affected the household's financial and human capitals of the displaced households. Farmers stopped their agricultural activities, women quite their sale of food and local drinks, many households stopped milk and poultry production. Majority of the productive members of the households have stopped engaging in income earning activities as they lost their old means of income generating activities. This condition has increased the households' exposure to food insecurity. The study revealed that the quality and quantity of food consumed by majority of the households are decreasing after the displacement.

The deterioration of financial capitals and social networks of the majority of the displaced households also resulted in income insecurity and livelihood crises which are resulted in socioeconomic marginalization of majority of the displaced households. The status of the displaced household's social capital indicates that their social networks such as family ties, neighborhood relations, ikkub, iddir and debo are weakened after the displacement. The family members, relatives and neighbors were dispersed to different directions in search of residential house while members of ekkub, iddir and debo have no strong link and mutual support as before the displacement. This condition has resulted in the weakening of the mutual help during socioeconomic crises. The new relocation village has no adequate basic social services such as road, pure water and electricity. These conditions have exposed women, girls and/or children to burdens such as fetching water and collecting fire wood.

The study uncovered that majority of the displaced households have experienced deterioration of economic assets such as landlessness, cattlelessness and joblessness; decline in productivity and food insecurity, socioeconomic marginalization, weakening of social networks and deterioration of access to community services after displacement. Deterioration in access to the livelihood assets due to the displacement has resulted in impoverishments of livelihood of majority of the displaced households. 


\subsection{Recommendations}

The negative impacts of development induced displacement can be minimized and development projects can be made beneficial to the affected people if proper measures are taken. Therefore, the following recommendations are forwarded to concerned stakeholders to minimize the risks of displacement affected peoples.

The government needs to devise a development policy that protects the interests of development induced displacement affected people. The policy, legal and institutional frameworks need to adopt clear provisions which include proper intervention before, during and after displacement. The frameworks need to have mechanisms of effective relocation/resettlement scheme to ensure effective rehabilitation of displaced households.

* The socioeconomic impacts of development projects should be carefully studied by experts and ways of reducing and/or avoiding risks of displacement based on specific situations of the subjects should be forwarded. The government needs to conduct a comprehensive socioeconomic impact assessment to identify the needs of various groups within the community to be displaced.

* Displaced households need to be consulted and participated in the planning of displacement and resettlement. Sufficient time should be given to prepare households to be displaced and adjust their livelihood to the impacts of displacement. Government should ensure that the affected population is actively participating at each stage of project implementations in order to address the adverse impacts of project induced displacement.

* Implementing agencies should plan for job creation for sustainable employment of displaced population to reduce and /or avoid the risks of joblessness. The affected population needs to be provided with training and capacity building projects and linked with micro level enterprises to enable them access sustainable job opportunities and income sources.

* Affected people should be provided with basic social services such as pure water, electric power, road, school, market and health. Government needs to increase investment in infrastructure, extending markets to the affected people, which in turn contribute to their livelihoods. Such services should be made available before relocation of displaced households.

* It will be better to have ways of preparing houses for displaced households before displacement so that displaced people can directly shifted to their own house. This could be conducted in two ways; either displaced households should be given a long period of time to construct their own house or government prepares houses with moderate payment by displaced households. This will save displaced households from crisis and unwanted expenditure in rent house which is found to be unbearable and risky for large family size farm households.

\section{Limitation of the Study and Future Research Direction}


This research is conducted on one of the twelve sites of displacement and resettlement during the Addis - Djibouti Lot One railway construction. The findings of this study are mainly based on the experiences of displaced population from one site. The findings of this research could not be generalized to the larger population evicted by the same project in the same year. Additionally, by the time this research is conducted, the target population was in the early stages of impoverishment risks and significant gradual changes in the livelihood of these people should be studied over a period of time by using longitudinal research. The livelihood strategies adopted by the displaced people also need scientific research to understand how people in resettlement setting react to socioeconomic hardships of displacement and adapt to new livelihood setting.

\section{Statement of Declaration}

I declare that I have no significant competing financial, professional, or personal interests that might have influenced the performance or presentation of the work described in this manuscript.

\section{List of Abbreviations}

FGD: Focus Group Discussion

SPSS: Statistical Package for Social Sciences

DPs: Displaced Person

\section{Compliance with Ethical Standards}

The research has committed to ethical standards of social science research; consent approval from all participated respondents, privacy, anonymity and other ethical standards of the field were strictly followed.

\section{References}

Berhanu, Z. (2006). Impact of Urban Redevelopment on the Livelihoods of Displaced People in Addis Ababa: The case of Casanchis Local Development Plan, MA thesis, Addis Ababa University.

Carino, J. K. (1999). Dams, indigenous people and vulnerable ethnic minorities: A case study on the Ibaloy people and the Agno River Basin, province of Benguet, Philippines. Http://www.dams.org (Accessed on February 04, 2013).

Cernea, M. (1997). The risk and reconstruction model for resettling displaced populations, World Development. Elsevier, 25(10), 1569-1587.

https://doi.org/10.1016/S0305-750X(97)00054-5

Cernea, M. (2000). Risks, safeguards and reconstruction: a model for population displacement and resettlement. Econ Polit Weekly, 35, 3659-3678. https://doi.org/10.1596/0-8213-4444-7

Cernea, M. (2003). For a new economics of resettlement: a sociological critique of the compensation principle. Int SocSci J., 55, 37-45. https://doi.org/10.1111/1468-2451.5501004 


\section{Ml Macrothink}

Journal of Agricultural Studies

ISSN 2166-0379

2019, Vol. 7, No. 3

Cernea, M. (2008). "Compensation and investment in resettlement: Theory, practice, pitfalls and needed policy reform", [In] Cernea, M. Mathur, H.M. (eds.), can compensation prevent impoverishment?: Reforming resettlement through investment and benefit sharing, Oxford University press, New Delhi, PP. 15-99.

Cernea, M. (2008). Compensation and benefit sharing: why resettlement policies and practices must be reformed. Water Sci Eng., 1, 89-120. https://doi.org/10.1016/S1674-2370(15)30021-1

Cernea, M. M. (1996). Development-Induced and conflict induced IDPs: bridging the research divide. http://www.fmreview.org (Accessed on March, 11/2013).

Downing, T. E. (2002). Avoiding new poverty: Mining-Induced Displacement and Resettlement. Mining-Induced Displacement and Resettlement.

https://pubs.iied.org/pdfs/G00549.pdf

Eguavoen, I., \& Tesfai, W. (2012). Social Impact and Impoverishment Risks of The Koga Irrigation Scheme, Blue Nile basin, Ethiopia: AFRIKAFOCUS, 25, 39-60.

https://doi.org/10.21825/af.v25i1.4962

Glenn, D. Israel. (1992). Determining the sample size: PEOD6; University of Florida, IFAS Extension: http://edis.ifas.ufl.edu, Accessed on June, 2014

Kassahun, K. (2011). Re-Relocation and Dislocation of Communities by Development Projects: The Case of Gilgel Gibe Dam (1962-2000) in Jimmazone. MA Thesis, Addis Ababa University and School of Graduate Studies: Addis Ababa.

Koenig, D. (2009). Urban Relocation and resettlement; Distinctive Problems, Distinctive Opportunities in Oliver-Smith, 2009. Development and dispossession, The crisis of forced displacement and resettlement. School for Advanced Research Press Santé Fe, New Mexico.

Mahapatra, L. K. (1999a). "Testing the Risks and Reconstruction Model on India's Resettlement Experiences." In M. Cernea (ed.) The Economics of Involuntary Resettlement: Questions and Challenges, Washington, DC: The World Bank.

Mathur, H. M. (1998). “Impoverishment Risk Model and its Use as a Planning Tool.” In H. M. Mathur and D. Marsden, (eds.) Development Projects andImpoverishment Risks: Resettlement Project-Affected People in India, Delhi: Oxford U.P.

Mathur, H. M. (1999). "The Impoverishing Potential of Development Projects. Resettlement Requires Risk Analysis." Development and Cooperation No. 6 Frankfurt: Deutsche Stiftungfür Internationale Entwicklung

Nebiyu, B. (2000). The Impact of Development-Induced Urban Resettlement Scheme on Relocated Households: The Case of Sheraton Addis Hotel Project. MA Thesis, Addis Ababa University and School of Graduate Studies: Addis Ababa.

Obsa, D. (2013). Effect of Large-Scale Agricultural Investment on Local Livelihoods: A Study of Bako-Tibe Karuturi Agro Products Plc: Norwegian University of Life Sciences (UMB), Norway; Stockholm 


\section{Macrothink}

Journal of Agricultural Studies

ISSN 2166-0379 2019, Vol. 7, No. 3

Robinson, W. C. (2003). Risks and Rights: The Causes, Consequences and Challenges of Development Induced Displacement. The Brookings Institution. Washington DC.

Scudder, T. (1997). Social Impact of Large Dam Project. In Z. D., ed., Large Dams: Learning from the past and looking at the future. Glen, Switzerland

Scudder, T., \& Culson, E. (1982). From Welfare to Development a Conceptual Analysis of Dislocated Peoplell, In Hansen, A, And Oliver Smith, AEds, Involuntary Migration and Resettlement. The Problems and Responses of Displaced People. Boulder and Colorado: West view Press.

Tadele, F. (2009). Urban development and displacement of rural communities around Addis Ababa, in: Alula Pankhurst\& Francois Piguet(eds,) Moving People in Ethiopia. Development, Displacement and the State. New York: James Carry, pp. 102-118.

Terminski, B. (2013). Development-Induced Displacement and Resettlement: Theoretical Frameworks and Current Challenges; Geneva. https://doi.org/10.2139/ssrn.2201987

World Bank, (2010). Rising Global Interest in farmland: Can it yield sustainable and equitable benefit? New York: The World Bank.

Yintso, G. (2008). Urban development and displacement in Addis Ababa. The impacts of resettlement projects on low income households, Eastern Africa Social Science Research Review, 24(2), 53-77. https://doi.org/10.1353/eas.0.0001

Zinawi, G. (2012). The Impact of Slum Renewal on the Livelihood of Displaced People in Addis Ababa: The Case of People Relocated to Jomo Resettlement Site. MA Thesis, AddisAbaba University and School of Graduate Studies: Addis Ababa.

\section{Copyright Disclaimer}

Copyright for this article is retained by the author(s), with first publication rights granted to the journal.

This is an open-access article distributed under the terms and conditions of the Creative Commons Attribution license (http://creativecommons.org/licenses/by/4.0/). 